\title{
A REVISION OF THE BEETLES OF THE TENEBRIONID TRIBE USECHINI, WITH DESCRIPTIONS OF A NEW GENUS AND NEW SPECIES
}

BY

FRANK E. BLAISDELL, $\mathrm{S}_{\mathrm{R}}$.

Professor of Surgery, Emeritus

Stenford Medical School

San Francisco, California
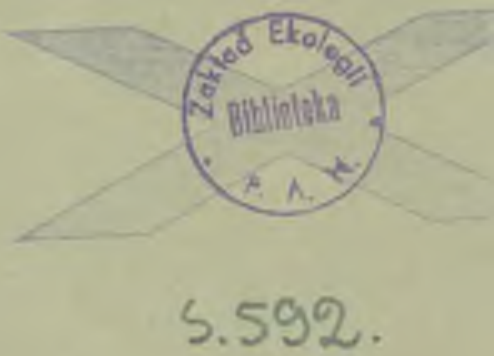

No. 2790.-From the Proceedings of the United States National Museum

Vol. 75, Art. 19, pp. 1-14, pl. 1
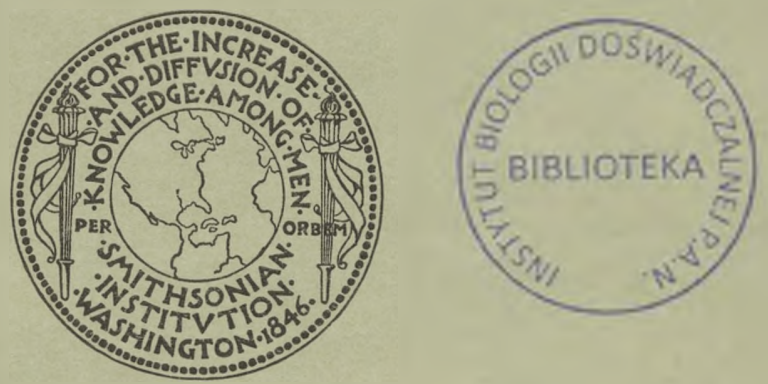

UNITED STATES

GOVERNMENT PRINTING OFFICE

WASHINGTON : 1929 
rcin.org.pl 


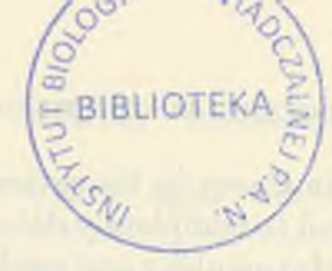

\title{
A REVISION OF THE BEETLES OF THE TENEBRIONID TRIBE USECHINI, WITH DESCRIPTIONS OF A NEW GENUS AND NEW SPECIES
}

\author{
By Frank E. Blaisdell, Sr. \\ Professor of Surgery, Emeritus, Stanford Medical School, San Francisco, California
}

The following revision is the direct outcome of having received a most remarkable addition to the tenebrionid tribe Usechini, which was transmitted to me as a loan for study by the late Dr. E. A. Schwarz and Mr. H.S. Barber of the United States National Museum. A careful examination of the morphological characters of Dsechus lacerta Motschulsky, the only previously known member of the tribe, revealed the need of a revision on account of a number of misstatements in the literature regarding the generic and specific characters.

It is, indeed, most surprising how errors regarding important structural characters have been set forth and perpetuated in works of a systematic nature intended for students' use. Such instances of inaccuracy are coming to light quite frequently under modern methods of study.

In the Classification of the Coleoptera of North America (LeConte and Horn), under the definition of the tribes of the Tentyriinae it is said on page 360 , that the eyes in the Usechini are round, and there given in direct dichotomous comparison with the Zopherini, when as a matter of fact the eyes are transverse in both of the tribes; and again, in the descriptive citation of the characteristics of the Usechini it is said (p. 365 of the classification) that the mentum conceals the maxillae at base and the ligula in part, which likewise is not correct for the cardo and stipes visibly fill the buccal fissures in the species described below. Another misleading statement (p. 365) is that regarding the antennae which are described as "ten-jointed, as the eleventh is closely united with the tenth, and is represented only by a pubescent space at the tip of the latter." Such is not the case, however, for the eleventh joint is oval, and more or less feebly transverse and not so closely united to the tenth as to be difficult of observation. In the Revision of the Tenebrionidae of America, Horn repeats the error regarding the eyes (p. 257) but corrects that concerning the eleventh antennal joint (p. 273).

\footnotetext{
No. 2790.-Proceedings U. S. National Museum, Vol. 75, Art. 19 $40747-29$ 
Col. T. Lincoln Casey in his review of the Tentyriinae ${ }^{1}$ improved matters, but failed to completely determine the character of the eyes in Usechus lacerta Motschulsky and nucleatus Casey, no doubt on account of the head of the insects being almost invariably deeply retracted into the prothorax. Even with a good series no attempt was made to extend the head to determine such an important character. Casey differs from Horn regarding the character of the epipleurae, saying that the elytra are without true epipleurae (p. 482 of the above paper). The present writer agrees with Horn in considering that true epipleurae are present and moderately well defined from the elytral disk.

Horn's definition of the family Tenebrionidae has to be modified so as to read: "Anterior coxal cavities usually closed behind, occasionally more or less open." According to his views it might be debatable as to whether or not the Usechini should be retained in the Tenebrionidae. He opposed the European entomologists in retaining Boros and Pytho, and others in the present family on account of the fact that they have the anterior coxal cavities open behind. It is my opinion that radical changes will have to be made in some parts of the Tenebrionidae when a more critical survey has been made of the genera and species. There is an urgent need for the study of the genitalia of the entire family.

In the classification the family Tenebrionidae is divided into three subfamilies, namely, Tentyriinae, Asidinae, and Tenebrioninae. In the Leng Catalogue it is divided into 22 subfamilies, the Asidinae (Asidini) being given as a tribe in the Tentyriinae. In the sequence of tribes the Usechini follows after the Nosodermini.

\section{Tribe USECHINI}

Body apterous, surface roughly sculptured; mandibles bifid at tip; mentum reiatively large, rounded at apex, not concealing the ligula or base of the maxillae; submentum with a spiculiferous puncture (male) at middle near base of mentum; antennae 11-jointed, outer 3 joints forming a club. Antennal fossae marginal and superior, invisible from beneath; eyes not convex, transverse and coarsely faceted. Anterior and middle coxae rather widely separated by the sterna; anterior coxae more or less open behind; middle coxal cavities inclosed by the sterna without trochantin; posterior coxae small, oval, distant; metasternum short, epimera linear; epipleurae entire, more or less moderately defined from the elytral disk, wide at base beneath the humeri. Legs short, tibiae with or without spurs; tarsi without plantar grooves beneath and sparsely clothed with hairs.

1 Proc. Washington Acad. Sci., v01. 9, 1907 pp. 481-484. 
The tribal secondary sexual characters have heretofore been considered obscure. In the male the submentum bears a distinct spiculiferous puncture at middle near the base of the mentum; the spicule s short, stout, and rigid.

\section{Genus USECHUS Motschulsky}

Usechus Motscholsiry, Bull. Soc. Imp. Nat. Moscou, vol 18, 1845, pt. 1, p. 79.

Form oblong-oval, moderately depressed. Eyes concealed in repose, transverse, separated above by a distance about equal to three times their greatest anteroposterior diameter, posterior border nearly straight-very feebly arcuate, very slightly to somewhat distinctly emarginate anteriorly behind the antennae, superior border rounded, truncated below by the prominent obtusely angled lateral border of the genae. The latter visible from above and slightly more prominent laterally than the sides of the front before the eyes. Tempora straight, parallel, and not more prominent than the eyes. Labrum short and transverse.

Antennae stout and gradually incrassate, short, joints closely articulated, basal joint shorter than the second and deeply seated in the antennal fossa; last three joints dilated, slightly compressed, forming a feebly differentiated and closely articulated 3-jointed club. Mandibles rather slender apically, deeply bifid, lobes acute, the superior slightly longer. Antennal fossae not entirely visible from above, but nearly hidden anteriorly by the horizontal sides of the pronotum.

Scutellum minute, of ten apparently absent, when present slender, entering but feebly between the elytra. Epipleurae flat in subhorizontal plane, rapidly broadening toward the base and more or less distinctly defined by a rough subcariniform line of asperities toward the humeri. Anterior coxal cavities more or less open behind. Tibial spurs apparently obsolete (invisible).

\section{USECHUS LACERTA Motschulsky}

Plate 1, figures 5, 8, 9

Usechus lacerta Motschulsky, Bull. Soc. Imp. Nat. Moscou, vol. 18, 1845, pt. 1, p. 79, pl. 1, fig. 9 .

Form elongate-oval, roughly sculptured. Color black to piceous, or paler according to degree of immaturity; luster dull to slightly shining. Pubescence sparse, yellowish, hairs short and subsquamiform, denser on the summits of the elytral tubercles.

Head and mouth parts small, frontal suture obsolete, epistoma truncate at apex, sides of the front strongly converging and slightly arcuate from the feebly convex supra-antennal convexities, angles moderately rounded. Front scarcely convex, impressed within the sides; moderately coarsely and sparsely punctate above and beneath, 
each puncture with a short decurved yellow hair. Antennal club not abruptly formed, ninth joint evidently not quite as wide as the eleventh, the latter transverse.

Pronotum as wide as long, widest at middle where the sides are subangulately prominent at end of the antennal fossae, thence strongly convergent and nearly straight to the apex, feebly convergent and slightly arcuate or feebly bisinuate to the basal angles, which are rectangular or feebly prominent laterally and slightly blunt; apex feebly emarginate and the angles obtuse and not prominent anteriorly; base broadly arcuate, sinuate near the angles; disk very moderately convex, impressed along the middle, often more or less obscurely so posteriorly; rather broadly and arcuately impressed and smooth behind the antennal fossae with the lateral margin quite s trongly reflexed, anteriorly slightly less so and forming the inner margin of the antennal fossa; surface coarsely but not densely tuberculose
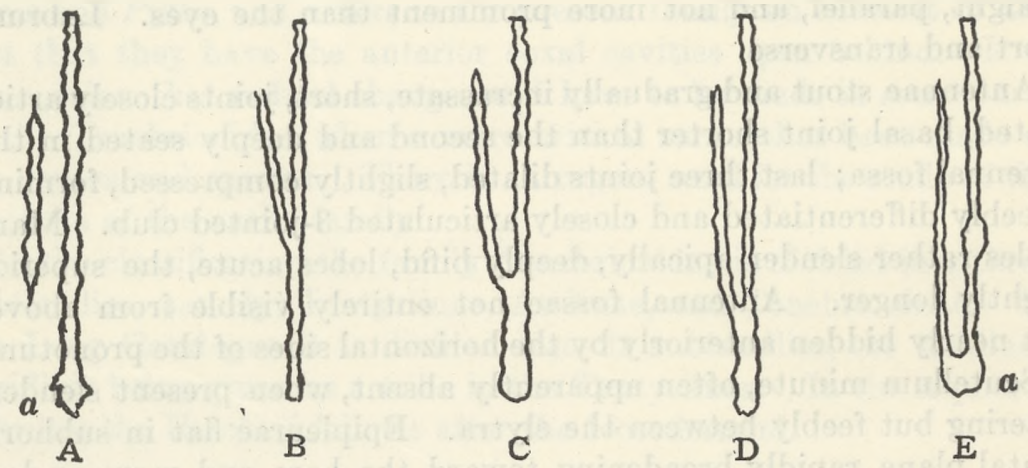

FIGURE 1.-DIAGRAM9 SHOWING RELATION BETWEEN THE FIFTH AND SEVENTH COSTATE INTERVALS OF TEE ELYTRA IN USECHU S: $a$ - $a$, SUMMIT OF THE APICAL DECLIVITT; A, LACERTA MOTSCEULSKT;

B. horni N. Var.; C. santaclarae N. VAR.; D, Trinitatis N. Var.; E, nucleatus Casey

and with an elongate-oval pitlike depression at middle near the base, and an antebasal transverse impression extending from near the basal angle to the side of the median impression.

Prosternum with coarse tubercles like those of the upper surface, each tubercle with a stiff yellow hair. Intercoxal process short, horizontal, truncate, and feebly bisinuate at apex, scarcely extending beyond the posterior border of the acetabula; surface impressed at middle of apex and within the lateral margins against the acetabula.

Elytra about one-half longer than wide, a little wider than the pronotum; sides parallel to feebly arcuate, broadly sinuate between the tubercle on the lateral margin of the declivity and the apical tumescence. Surface coarsely punctate, punctures in single rows and the alternate intervals costate as follows: Intervals 3,5 , and 9 , distinctly costate, the seventh feebly so, but not joining the fifth at 
tubercle on summit of the apical declivity (fig. 1, A); third costa entire and bituberculate posteriorly - at summit and middle of the declivity, ending in the apical tumescence; ninth costa submarginal and entire, continous with the reflexed humeral margin anteriorly and ending in the apical tumescence posteriorly, being distinctly tuberculate at middle of the apical declivity laterally. Interval four not in the least convex, sixth and eighth nearly or quite obliterated, all irregular from the two adjoining series of coarse punctures; the sutural interval becomes distinctly convex at sides of the scutellar depression and attains the basal margin independantly of the third, the two expanding on the basal edge and forming a prominent margin. Second and third series of punctures very deep and perforate in the central and basal portion of the disk, each puncture bounded laterally by a small decurved and overhanging tubercle, punctures usually filled with detritus. Intrahumeral impressions asperately sculptured. Scutellar depression scarcely declivous anteriorly, scutellum narrowly triangular, very small, feebly or not at all entering between the elytra.

Abdomen with the ventral sutures deeply impressed, apical and basal margins abrupt and more or less crenulate; segments 1,2, and 3 almost impunctate laterally. Lateral margins of the segments thick, especially that of the fif th at apex; the fifth rather deeply impressed laterally and subcarinate on the median line. Under surface of the body very coarsely punctate. Tarsi short and slender; claws small and slender.

Male. - Abdomen very feebly impressed in middle third of segments $1,2,3$. Surface of fifth segment more strongly impressed laterally, less convex, the impression divided by a median convexity. Posterior margin of the anterior coxal cavities more or less narrowly open.

Female.-Abdomen evenly convex. Fifth ventral less broadly impressed and more in the form of a coarse submarginal groove; posterolateral triangular area of the first segment impunctate. Posterior margin of the anterior coxal cavities slightly more widely open.

Measurements.-Length 3.1-5.5 mm.; width 1.4-2.1 mm.

Distribution.-California (Duncan Mills, Sonoma County, July 16, 1908; Lagunitas, Marin County, September 22, 1912).

Habitat.-On fungus and under moldy bark of dead trees where slightly humid.

In addition it may be noted that in lacerta the pronotal discal impression behind each antennal fossa is impunctate, that the costate seventh elytral interval ends at basal fifth behind the humeral impression. The sutural rows of punctures attain the margin between the apical tumescences, the latter being mainly in line with the costate third interval; the costate basal parascutellar portion of the sutural interval curves slightly outward around the scutellar impression, the latter rather cavernously unipunctate each side beneath the costae. 
The tenth interval on the deflexed side of the elytral disk is invisible from above, slightly costate, joins the epipleural margin just behind the humeri and posteriorly attains the outer part of the apical tumescence. The epipleural margin attains the humeral angle and elytral apex; the submarginal line of punctures is quite entire.

On account of lacerta Motschulsky being the type of the genus it has been described in detail. This is necessary to differentiate three other phases that are considered to have racial characteristics.

\section{USECHUS LACERTA HORNI, new variety}

Plate 1, figures 2, 6

The variety horni differs from lacerta Motschulsky in its smaller size and feebly convex alternate elytral intervals. The elytral tubercles are entirely obsolete or feebly developed. The seventh elytra costa (fig. 1, B) joins the fifth at about apical third of costa and the sixth interval is obsolete anterior to the union; eighth interval obsolete between the two rows of serial punctures internal to the costate ninth interval, the latter not in the least tuberculate at sides of the apical declivity, although in some specimens an incipient tubercle may be present. Anterior coxal cavities more or less open posteriorly.

The antennal club is narrower, joints 10 and 9 quite equal, eleventh more rounded and scarcely longer than wide.

Measurements.-Length (type) $3.8 \mathrm{~mm}$; width $1.25 \mathrm{~mm}$.

Type locality.-California (Duncan Mills on the Russian River, Sonoma County). Collected on July 16,1908, by the writer. A small series studied. Type a male in the author's collection. Paratypes in the United States National Museum and California Academy of Sciences collections.

Paratypes.-Cat. No. 40378. U.S.N.M., from Santa Cruz Mountains, Calif. (Koebele).

\section{USECHUS LACERTA SANTACLARAE, new variety}

Plate 1, figure 7

Form rather more robust than lacerta Motschulsky less parallel and less roughly sculptured. Color castaneous to nigro-piceous. Antennae less heavy, club more abruptly formed and there is a greater and more noticeable difference between the width of the eighth and ninth joints; the ninth and tenth very nearly equal in width and length; eleventh slightly transversely oval. Prothoracic basal impressions usually deep. The tubercles formed by union of the fifth and seventh convex elytral intervals more elongate on summit of the declivity. (Fig. 1, C.)

Measurements.-Length (type) $6 \mathrm{~mm}$; width $2.2 \mathrm{~mm}$. 
Type locality.-Santa Clara County, Calif. Four specimens without other data in the Van Dyke collection. Type a male and paratype in the collection of the California Academy of Sciences, and one in the author's collection. A paratype has also been deposited in the collection of the United States National Museum in Washington. Other specimens from the Koebele collection are in the California Academy of Sciences and in the United States National Museum.

Paratype.-Cat. No. 40379, U.S.N.M.

Distribution.-Santa Cruz Mountains of California.

USECHUS LACERTA TRINITATIS, new variety

Less elongate and rather more robust than lacerta Motschulsky, surface less roughly sculptured. Sides of the prothorax more prominently angulate across the extremities of the antennal fossae, thence more strongly convergent anteriorly to the apex. Pronotal disk quite strongly sculptured, median groove broad, well defined by prominent borders and basal impression rather deep.

Elytral sides more arcuate, the intervals nearly as in lacerta: third most pronounced on the apical declivity, seventh joining the fifth (fig. 1, D) at about middle, thence quite prominent to opposite tubercle of ninth; sixth interval slightly indicated between the strial punctures, ninth very feebly angulate laterally at side of the declivity. Discal punctures very coarse in the first four series.

Antennal club less strongly developed than in lacerta. Ninth and tenth joints about equal in length and width, the eleventh more rounded, about as long as wide and scarcely as wide as the tenth. First ventral segment feebly but distinctly impressed at middle.

Measurements.-Length (type) $4.5 \mathrm{~mm}$.; width $1.6 \mathrm{~mm}$.

Type locality.-Trinity County, Calif. Collected on January 17, by E. R. Leach. Two specimens studied, holotype, male and, allotype, female. Types in the author's collection to be deposited in the collection of the California Academy of Sciences.

The variety trinitatis might correctly be considered a subspecies, but on account of the small number of specimens studied it has been thought best to give it a minimum grade.

\section{USECHUS NUCleatus Casey}

Plate 1, figure 1

Usechus nucleatus CASEY, Ann. New York Acad. Sci., vol. 5, p. 176. Mar. 1890.

Form very much smaller in size, less elongate and relatively broader than lacerta Motschulsky. Color brown-black to piceo-testaceous and duller in luster. Pubescence sparse, consisting of slender yellow subsquamiform hairs, denser on or at site of the tubercles.

Head finely and sparsely punctate. Eyes transverse, rather broadly rounded above, broadly and very feebly emarginate behind the antennae. The latter less stout than in lacerta; first two joints a 
little longer than wide, second as long as wide, others subequal in length and slightly transverse; ninth and tenth more prominent anteriorly; eleventh oval and about the same length as the tenth.

Pronotum nearly similar to that of lacerta, but with the median discal impression more or less obsolete near the middle, with basal pit deeper and rather more circular. The latter bounded laterally by rather prominent margins that are somewhat faceted lateroposteriorly at point of contact with the basal elytral processes.

The antennal fossae extend further posteriorly than in lacerta to a little distance behind the middle; their inner margin very moderately reflexed. Disk broadly impressed behind the fossae and within the reflexed lateral margin; the impressions extend inward along the basal margin to the sides of the basal pit, are shallow and not abruptly formed, with surface subglabrous.

Prosternal process truncate and flush with the posterior border of the coxal cavities, as well as strongly margined against the acetabula.

Elytra coarsely sculptured, punctures large in regular series and moderately deep. Intervals more or less discernable throughout between the rows of punctures; the third, fifth, seventh, and ninth rather moderately subcostate in greater part of their length; the third being so for its entire length and terminating in the apical tumescence, much thickened at base and joining the feebler parascutellar ridge from the sutural interval, the two together forming a moderately prominent and anteriorly projecting short process that overhangs the basal pronotal margin, evidently abutting against the dorsolateral facet on side of the basal pit when the prothorax is retracted against the elytral base; laterally the process is continuous with the basal margin, but abruptly formed medially, somewhat flattened and moderately arcuate at apex. The second interval is not convex anteriorly and is lost between the first and third behind the basal process; seventh interval (fig. 1, E) is moderately costate, beginning just behind the intrahumeral impression and terminating posteriorly with the fifth in a small tuberculiform swelling at summit of the apical declivity. The sixth and eighth intervals are noticeably feebly convex, but irregular from the adjacent strial punctures; ninth is costate throughout and submarginal and not tuberculate at side of the apical declivity. The epipleural margin on the deflexed sides of the elytra meets the ninth interval at the humeral angle. The humeral margin is moderately reflexed and the angle obtuse; the intrahumeral impressions are glabrous as well as the triangular periscutellar space which is slightly anteriorly declivous and usually quadripunctate. The scutellum is minute, elongate, and enters but feebly or not at all between the elytra.

Abdomen almost impunctate toward the sides, especially in the lateroposterior portion of segments one and two, which are much 
more finely punctured elsewhere, except on the basal segment; impressions of the fifth only moderately marked. The first segment is very broadly, feebly flattened at middle and between the coxae, where the punctures are large, circular and shallow. The metasternal surface between the four acetabula is distinctly and broadly impressed with edges of the area slightly raised.

Male.-Submentum with a spiculiferous puncture. Middle of the ventral abdominal segments slightly but appreciably impressed, the impressed area gradually diminishing in extent from the second toward the fifth; the latter more strongly impressed and feebly pitlike at the sides within the marginal bead.

Female.-Submental puncture obsolete or minute. Middle third of the first ventral segment impressed as in the male, the following segments being evenly convex from side to side; the fifth more convex at middle and less impressed as a whole within the thick marginal bead, the lateral pitlike depressions being smaller but noticeable.

Measurements.-Length 2.9-4.3 mm.; width 1.18-1.6 mm.

Six specimens studied. Casey's types have been deposited in the United States National Museum. Two of the four specimens believed to be paratypes, given long ago by Col. T. Lincoln Casey to Dr. E. A. Schwartz, were kindly transmitted to me for study and contributed to the above revision of Casey's description. The type has recently been examined by the author during a visit to the Museum in Washington. Two other specimens from the same museum are from Oregon (Linell collection) and the State of Washington (Morrison). The two other specimens were received as a loan from Professor Beamer of the entomological department of the University of Kansas. Casey writes that he had a large series before him at the time he described the species, but I am informed that his series now consists of 14 specimens, the labels of 3 of which indicate "Hoopa Valley, Trinity River, Humboldt County (Fort Gaston)" (the type locality), 1 indicates Arcata in the same county, and 10, which he probably considered duplicates unworthy of complete labels, bear only the State label "Cal." He overlooked the basal elytral processes. Casey's type is illustrated by photograph. Plate 1 , figure 1.

In nucleatus all of the elytral intervals are more or less recognizable. It has therefore served as a criterion for the determination of the intervals in lacerta where part of the intervals are obsolete on account of the closeness of the strial punctures.

\section{USECHIMORPHA, new genus}

Form subquadrato-oblong. Eyes deeply concealed in repose, transverse, anterior and posterior borders parallel, quite straight and not emarginate anteriorly, distinctly narrower than in Usechus Mots- 
chulsky, and equal in width throughout, except at the upper border where they are subacute and slightly arcuate anteriorly; lower border truncated by the prominent lateral edge of the genae, separated on the vertex by a distance less than twice their own width. Labrum well developed.

Antennae not stout, funicle rather slender, joints three to seven equal in width, eighth widest and truncated at apex as seen from below; terminated by a well formed, short oval and somewhat compressed 3-jointed club; eleventh joint much smaller than the tenth and rounded at apex. Mandibles not deepely emarginate at tip, lobes short, subobtuse and subequal. Tempora rather long, straight, parallel, very feebly convergent posteriorly, less prominent than the

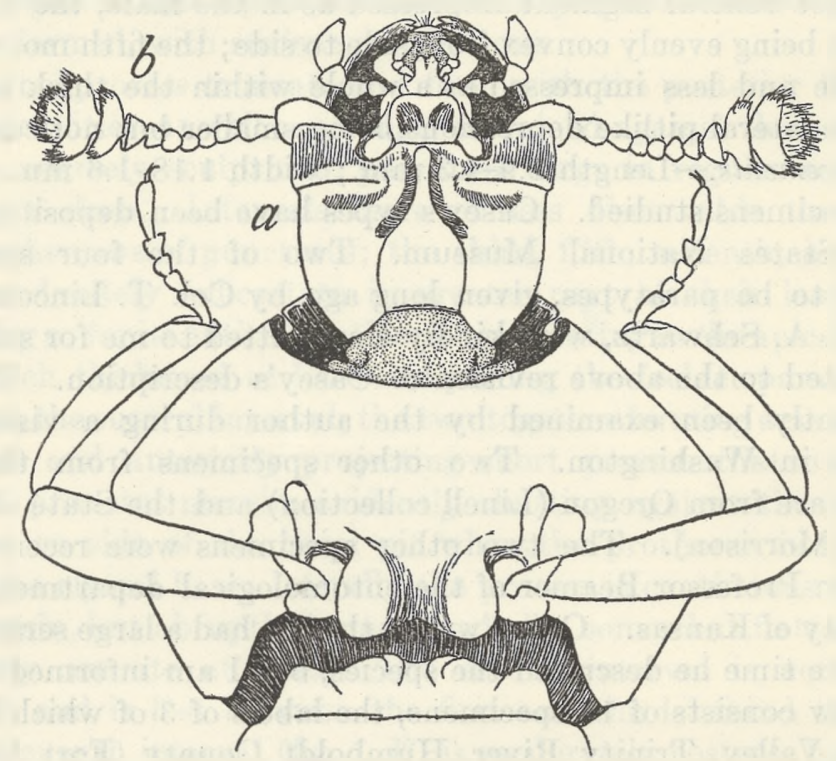

FIGURE 2,-USECHIMORPHA BARBRRI, $a$, HEAD FULLY EXTENDED AS SEEN FROM BENEATH; b. ANTENNA, BASAL JOINT NEARLY CONCEALED BY THE GENIAL PLATE

lateral border of the genae, the latter slightly wider than long and visible from above. The head widest between the anterolateral angles of the genae. Antennal fossae rather large, open, dorsal and marginal, wholly visible from above.

Anterior coxal cavities widely open posteriorly, prosternal process broad. Scutellum very small, elongate and entering for a short distance between the elytra at base. Intercoxal process of the first abdominal segment broad, truncate between the coxae. Tibial spurs small, slender, and distinct.

In Usechimorpha there is in the median line of the submentum, near to base of the mentum, a moderately coarse spiculiferous puncture; 
spinule short and stout and probably a male character. A similar structure occurs in the species of Usechus.

Genotype.-Usechimorpha barberi, new species.

USECHIMORPHA BARBERI, new species

Plate 1, figures 3,4

Color rufo-piceous, surfaco abundantly clothed with small decurved yellowish, slender scalelike hairs; surface more or less coated with a light gray scaly substance.

Head and mouth parts relatively small. Epistomal region before the antennae depressed, obsoletely sculptured and sparsely pubescent, abruptly and arcuately limited above by the raised surface of the front before the eyes; epistomal apex broadly arcuate between the feeble sinuations at the positions of the oblique sutures, angles moderately rounded with the sides of the front, surface feebly convex. Front between and anterior to the eyes obsoletely sculptured and glabrous; vertex finely and subasperately sculptured. Labrum transverse, arcuate at apex, surface with few punctules and very fine hairs. The sharp lateral borders of the genal plates are visible from above and the basal joint of the antennae at apex is nearly flush with it. Head in repose retracted to the raised frontal line.

Antennae clavate, length slightly greater than the width of the head across the eyes; basal joint less than twice as long as wide, second scarcely longer than wide, third to the serenth, inclusive, subequal in size and form, about as long as wide, short and subcylindrical; eighth wider, scarcely longer, flaring and acutely margined at apex; joints two to eighth, inclusive, form a rather slender funicle. Ninth and tenth joints strongly transverse, the former twice as wide as the eighth, tenth a third wider than the ninth, the tenth rather deeply and arcuately emarginate receiving the smaller eleventh joint. Joints ninth, tenth, and eleventh forming a slightly compressed, oval club.

Pronotum as long as wide, widest at about middle across the apices of the antennal fossae and there broadly angulate, thence the lateral edge of the antennal fossae is straight, convergent, slightly declivious anteriorly but not extending as far forward as the inner border of the fossa, straight posteriorly and equally convergent to the obtuse basal angles; base rather strongly arcuate and apparently finely margined; basal angles more acutely rectangular beneath the more superficial obtuse line; apex truncate in feeble circular arc between the slightly rounded angles; disk irregularly convex, narrowly impressed along the median line from the apex, becoming more broadly so behind the middle, rather arcuately declivious anterolaterally forming the inner boundary of the antennal fossae which are wholly visible from above as the result; surface obscurely quadritumescent, 
deeply impressed behind the fossae within the somewhat thickened and more or less reflexed lateral margins, deeply and transversely impressed at middle before the basal lobe, continuously so with the lateral impressions.

Elytra about a third longer than wide, about as wide as the pronotum, sides parallel in basal three-fifths and slightly arcuato-undulate, thence moderately convergent to apex which is not broadly rounded; base feebly emarginate and adapted to the pronotal base; humeri moderately rounded and not tumescent; surface irregular from rather large incipient oval tubercles, which become most pronounced at and on the upper apical declivity, there are also discernable two lateral and a median one on each ely tron, the former being most conspicuous. A small depression within each humerus is usually present.

Ventral surface of the body pubescent as above. Prosternum not tuberculose although rather irregular, the propleurae obscurely subtuberculose; prosternal process slightly emarginate at apex; metasternum somewhat broadly impressed in the central area. Abdominal sutures not excavated, first and second feebly arcuate, fifth ventral not impressed. Legs rather short and slender; tarsi slender.

Measurements.-Length $3.2 \mathrm{~mm}$.; width $1.4 \mathrm{~mm}$.

Holotype.-Cat. No. 28851, U.S.N.M.

Type locality.-Near Eureka, Humboldt County, Calif.

Described from a single specimen, a male, deposited in the collection of the United States National Museum, Washington, D. C.

Collected by H. S. Barber, to whom the species is dedicated. $\mathrm{He}$ writes concerning the specimen as follows: The beetle was taken while "sifting leaf-litter in a coniferous woods along a road 2 miles east of the center of Eureka, Humboldt County, Calif. It was taken together with the similarly obscure colydiid Megataphrus."

Usechimorpha barberi stands as an example of what can be obtained by careful sifting, a method of collecting nearly entirely neglected of late. Collectors desire larger and more spectacular things, something to make a show. Sifting may be irksome but it is less strenuous. Among the microcoleoptera are found some of the most marvelous and curious forms.

A synoptical statement of the differential characters for separating the genera and species of the $U$ sechini described above may be given as follows:

KEY TO GENERA. OF USECHINI

Antennae with a feebly differentiated club; funicle stout; epistomal region of the head convex; anterior coxal cavities more or less imperfectly closed behind Usechus Motschulsky

Antennae with a well formed oval club; funicle slender; epistomal region distinctly impressed; anterior coxal cavities widely open behind.

Usechimorpha, new genus 
The species of the genus Usechus may for the present be separated in the following manner:

\section{KEY TO SPECIES OF USECHUS}

Elytral base without processes overhanging pronotal base; surface roughly sculptured; elytral intervals in part obliterated by juxtaposition of the coarse serial punctures.

Form elongate, parallel, coarsely sculptured; seventh costa discrete, rarely joining the fifth, ninth, or pseudomarginal costate interval strongly tuberculate at side of apical elytral declivity; antennal funicle stout, eleventh joint wider then Jong .............lacerta Motschulsky

Form relatively broader, much less roughly sculptured; costate seventh interval joining fifth at tubercle on summit of declivity, tubercle long; costate ninth interval simply angulate at side of declivity; antennal funicle stout, eleventh joint as in lacerla........ santaclarae, new variety

Form small, relatively robust, less roughly sculptured; costate intervals devoid of tubercles (type), or tubercles incipient; costate seventh interval joining fifth at middle of elytra; antennal funicle less stout, eleventh joint scarcely transverse...............horni, new variety

Form similar to nucleatus, relatively more robust, sides more arcuate, much less roughly sculptured as in santaclarae; costate seventh intervai joining fifth at tubercle, the latter elongate; costate ninth interval angulate at side of declivity; ninth and tenth antennal joints less transverse, club as long as wide...........trinitatis, new variety

Elytral base with short processes overhanging pronotal base; elytral intervals more or less distinct between the rows of punctures; costate seventh interval joining fifth at tubercle, the latter round; costate ninth interval feebly tuberculate at side of apical declivity

As a final test of the stability of certain characters it was found that out of 26 lacerta Motschulsky, 20 had the costate seventh interval discrete; in 4 that interval joined the fifth, while in 2 , the seventh was discrete on one side and joined the fifth on the other.

In 10 specimens of Santaclarae, the seventh interval joined the fifth in all except 1 , in that one the seventh was discrete. In this variety the tubercle of the seventh is elongate and ridgelike, while in lacerta it is shorter and rounded. The differential characters appear to hold in a series and differ no more than in other species, subspecies, and varieties.

There is no question regarding the specific distinctness of lacerta and nucleatus. Typical horni is unique. Larger series are needed for study.

On account of the difficulty of obtaining Motschulsky's works it is thought best to give his descriptions of the species involved in the present paper as an addendum. 


\section{ADDENDUM}

The following is an excerpt of Motschulsky's writings, $1845:^{2}$

228. USECHUS m. nov. gen.

Hétéromère. Les quatre antérieurs de cinq, les postérieurs de quatre articles; dernier article des tarses presque de la longeur de tous les précédents ensemble. Tête petite, chaperon arqué, recouvrant en grande partie la lèvre supérieure et les mandibules; yeux cachés sous le chaperon. Palpes courtes et larges, dernier article ovolaire. Antennes n'atteignant pas le milieu du corselet, moniliformes avec les trois derniers articles en massue tronquée. Corselet beaucoup plus large et plus long que la tête, avec une cannelure profonde de chaque côté pour recevoir l'antenne. Elytres presque paralleles, convexes et couvertes d'élevations et d'inégalitiés comme celles des Bolitophagus et Endophloeus. Fascies des Endophloeus.

USECHUS LACERTA. m. Tab. 1. fig. 9-9'. [See Plate 1, fig. 5.]

Elongatus, convexus, cribratus, squalidus, brunneus, parce setulosus; capite minuto thorace subquadrato, antice angustato, lateribus reflexis, crenulatis; scutello triangulari; elytris carinatis, interstitiis elongato scrobiculatis, carinis postice in verrucae productis.

Long. $21 / 2$ lign. Larg. 1 lign.

Il ressemble par sa taille et ces couleurs à l'Endophloeus exculptus Parreys, mais les côtes sur les élytres sont moins relevées et les excavations latérales, qui recoivent completement les antennes redressées en arrière, le font facilement reconnaître.

Il m'a été envoyé comme venant de Californie."

Plate 1, fig. 9-9'. The figure is hand colored, dull brown and shows no more than the photograph [Plate 1, fig. 5] shows.

\section{EXPLANATION OF PLATE}

(Photographs by H. S. Barber)

Figures enlarged about 10-13 diameters

EigdRe 1. Usechus nucleatus Casey. Type.

2. Usechus lacerta horni Blaisdell. Paratype from Santa Cruz Mountains, California.

3-4. Usechimorpha barberi Blaisdell. Type. Ventral and dorsal aspects.

5. Usechus lacerta Motschulsky. Enlargement of original hand-colored figure. (Bull. Soc. Imp. Moscou, 1845, vol. 18, pl. 1, fig. 9.)

6. Usechus lacerta horni Blaisdell. Enlargement of figure by Horn (Trans. Amer. Philos. Soc., vol. 14, pl. 15, fig. 5) there called lacerta Motschulsky.

7. Usechus lacerta santaclarae Blaisdell. Paratype.

8-9. Usechus lacerta Motschulsky. Dorsal and ventral aspects of a specimen from Lagunitas, Marin County, Calif.

Bull. Soc. Imp. Nat. Moscou, vol, 18, p. 79.

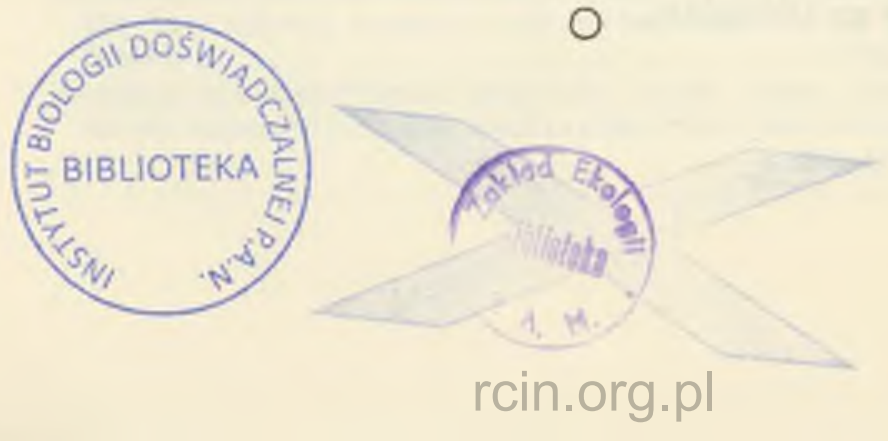


U. S. NATIONAL MUSEUM
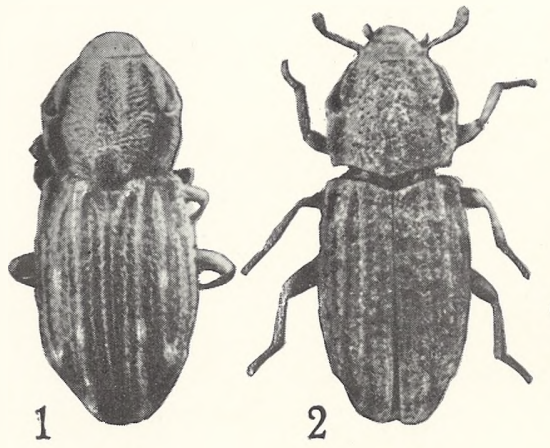

2

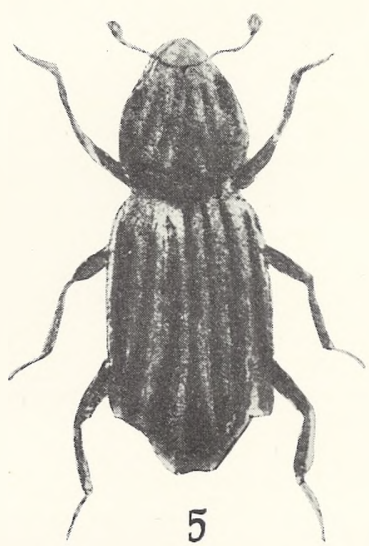

5
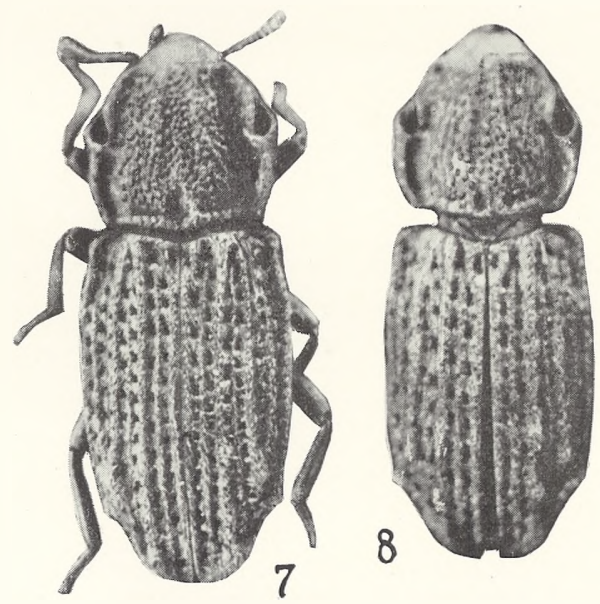

VARIOUS SPECIES OF USECHUS AND USECHIMORPHA

FOR EXPLANATION OF PLATE SEE FAGE 14
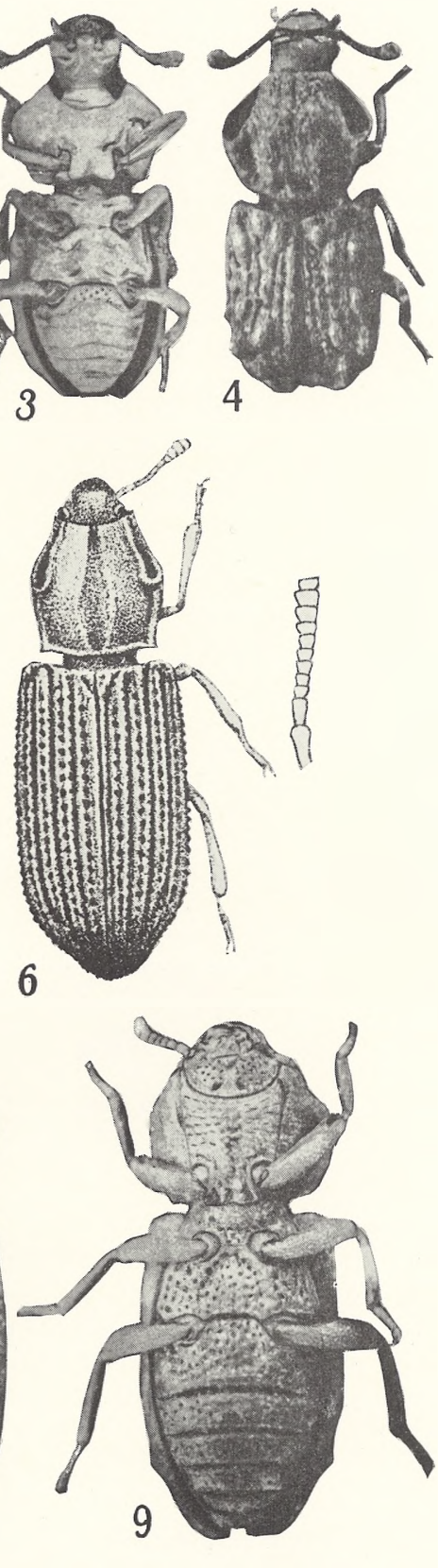


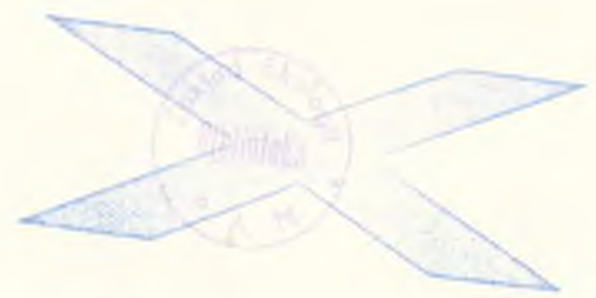

rcin.org.pl 
rcin.org.pl 
rcin.org.pl 
rcin.org.pl 
1 